\title{
ABOUT THE EGYPTIAN NATURAL GAS; AN OVERVIEW, HISTORY AND PROSPECTS
}

\author{
Abbas, N.S ${ }^{(1)(3)}$, Assfour, H.M ${ }^{(2)}$, Abdel wahhab, M.Z. ${ }^{(2)}$ And' Ashour, E.A ${ }^{(2),}$ \\ ${ }^{(1)}$ Process Section head, (GUPCO), Cairo, Egypt. \\ ${ }^{(1)}$ Professors, faculty of Engineering, Minia University, Minia, Egypt. \\ ${ }^{(2)}$ Correspondence person, at the address of prof. Dr. Assfour (Dept. of chem. Eng.),Faculty of engineering, Minia \\ University.
}

\section{1-ABSTRACT:}

Egypt became a net importer of natural gas in 2015 because of its growing domestic demand and declining production levels. Substantial natural gas discoveries in 2018 have generated significant interest among business investors and may potentially boost production and allow Egypt to become a net exporter again in the medium term that began from Dec.2018. Total natural gas reserves are expected to significantly increase within the next few years because of the recent natural gas discoveries, especially Zohr, Atoll and Nour fields.

Keywords: Natural gas, Egyptian natural gas, Zohr field, fossil fuels, petrochemicals.

\section{2-INTRODUCTION:}

Egypt produced approximately 4.0 billion cubic feet per day $(\mathrm{Bcf} / \mathrm{d}),(0,11326$ billion cubic meter per day $\mathrm{Bcm} / \mathrm{d}$ ) of dry natural gas and imported $1.0 \mathrm{Bcf} / \mathrm{d},(0.0283$, $\mathrm{Bcm} / \mathrm{d})$ in 2016. To satisfy growing domestic demand, Egypt has had to divert its natural gas supply away from exports to the domestic market and to rely on liquefied natural gas (LNG) imports to address the shortfall in consumption. The Egyptian government has fast-tracked the development of the Zohr and Atoll fields and the West Nile Delta (WND) project. These fields are expected to make substantial additions to the overall supply. Discovered in August 2015 and labeled as the largest offshore natural gas field in the Mediterranean, the Zohr gas field has an estimated reserve of 30 Trillion cubic feet (Tcf) and is to be, by the end of 2019 currently producing $2(\mathrm{Bcf} / \mathrm{d}), 0.0566(\mathrm{Bcm} / \mathrm{d}$
)) [1]. Consumption of natural gas (NG) in all end-use classifications (residential, industrial, commercial \& power generation) increased rapidly since the world war II. This growth resulted from several factors, including development of new markets, replacement of coal as fuel for providing industrial process heat. Use of $\mathrm{NG}$ in making petrochemicals and fertilizers, made a strong demand for lowsulfur fuels to be used as liquefied petroleum gas (LPG).

(3) correspondence person, at the address of prof. Dr. Assfour (Dept. of chem. Eng.) 


\section{Vol. 39, No. 2. July 2020}

\section{3 - EVALUATION:}

\section{(A) By Analysis:}

Natural gas accumulations in geological traps can be classified as reservoir, field, or pool. A reservoir is a porous and permeable underground formation containing an individual bank of hydrocarbons confined by impermeable rock or water barriers and characterized by a single natural pressure system. A field is an area that consists of one or more reservoirs all related to the same structural feature. A pool contains one or more reservoirs in isolated structures. Wells in the same field can be classified as gas wells, condensate wells, and oil wells. Gas wells are wells with production gas-oil-rations
(GOR) greater than 100,000 (scf/stb) standard cubic feet at standard temperature and pressure; condensate wells are those with producing GOR being less than 100,000 $\mathrm{scf} / \mathrm{stb}$ but greater than $5,000 \mathrm{scf} / \mathrm{stb}$; while wells with GOR being less than 5,000 scf/stb are classified as oil wells. There are three types of natural gases: Non associated gas, associated gas, and gas condensate. Non associated gas is from reservoirs with minimal oil. Associated gas is the gas dissolved in oil under normal conditions in the oil reservoir. Gas condensate refers to gas with high content of liquid hydrocarbon at reduced pressures and temperatures. Table (1) gives chosen examples for the gas produced from some fields in Egypt.

Table (1): Typical Analysis of Some Egyptian Natural Gas Productions [2]

\begin{tabular}{|c|c|c|c|c|c|c|c|c|c|c|c|}
\hline company Analysis & $\begin{array}{l}\mathbf{N}_{\mathbf{2}} \\
\%\end{array}$ & $\begin{array}{l}\mathrm{C}_{1} \\
\%\end{array}$ & $\begin{array}{l}\mathrm{CO}_{2} \\
\%\end{array}$ & $\begin{array}{l}\mathrm{H}_{2} \mathrm{~S} \\
\text { PPM }\end{array}$ & $\begin{array}{l}\mathrm{C}_{2} \\
\%\end{array}$ & $\begin{array}{l}\mathrm{C}_{3} \\
\%\end{array}$ & $\begin{array}{l}\mathrm{IC}_{4} \\
\%\end{array}$ & $\begin{array}{l}\mathrm{NC}_{4} \\
\%\end{array}$ & $\begin{array}{l}\mathbf{I C}_{5} \\
\%\end{array}$ & $\begin{array}{l}\mathrm{NC}_{5} \\
\%\end{array}$ & $\begin{array}{l}\mathrm{C}_{6}^{+} \\
\%\end{array}$ \\
\hline GUPCO feed & 0.499 & 79.668 & 0.648 & 45.800 & 10.578 & 5.290 & 0.757 & 1.574 & 0.434 & 0.377 & 0.175 \\
\hline GUPCO sales gas & 0.538 & 85.587 & 0.655 & 1.000 & 11.075 & 2.000 & 0.084 & 0.025 & 0.024 & 0.012 & 0.000 \\
\hline AMAL company & 0.405 & 80.023 & 0.247 & 0.000 & 10.295 & 5.550 & 0.889 & 1.708 & 0.445 & 0.361 & 0.077 \\
\hline SUCO company & 0.563 & 80.403 & 1.802 & 1.000 & 10.559 & 4.658 & 0.522 & 1.020 & 0.231 & 0.196 & 0.046 \\
\hline SAQQARA field & 0.406 & 73.906 & 1.187 & 5.000 & 12.958 & 6.912 & 0.995 & 2.287 & 0.603 & 0.587 & 0.159 \\
\hline
\end{tabular}

\section{(B)By Uses:}

The composition of natural gas varies considerably from location to location, and as with petroleum products in general, the specifications for salable products from Gas processing are generally in terms of both composition and performance criteria. For natural gas, these criteria include Wobbe number, heating value, total Inerts, water, oxygen, and sulfur content. The first two criteria relate to combustion characteristics, while the latter three provide protection from pipeline plugging and Corrosion.

\section{4- NATURAL GAS PRODUCTION:}

\section{(A)Egyptian Natural Gas Productions:}

Similar to crude oil reserves, estimates of natural gas reserves also vary across publications. Natural gas reserves in Egypt were a constant 77.2 trillion cubic feet (Tcf) (2.2 trillion cubic meter Tcm) since 2011, an increase from 58.5 (Tcf) $(1.65 \mathrm{Tcm})$ in 2010[3]. According to the 2017 BP Statistical 


\section{Vol. 39, No. 2. July 2020}

Review of World Energy, Egypt held approximately 65.2 (Tcf) 1.84 (Tcm) of proved natural gas reserves at the end of 2016, which is an increase from the 2010 estimate of almost 59 (Tcf), 1.67(Tcm) and which is also the fourth-largest amount in Africa, after Nigeria, Algeria, and Mozambique [4]. Total natural gas reserves in Egypt are expected to significantly increase within the next few years because of the recent natural gas discoveries from 2016 to 2018. Despite new discoveries, Egypt's dry natural gas production declined by $31 \%$ from 2012 to 2016, leading to net imports since 2015. Egypt produced approximately 4.0 $(\mathrm{Bcf} / \mathrm{d}),(0.11326(\mathrm{Bcm} / \mathrm{d}))$ of dry natural gas and imported $1.0 \mathrm{Bcf} / \mathrm{d}(0.0283(\mathrm{Bcm} / \mathrm{d}))$ in 2016[5]. To satisfy growing domestic demand, Egypt has had to divert its natural gas supply away from exports to the domestic market and to rely on liquefied natural gas (LNG) imports to address the shortfall in consumption. Egypt acquired two floating storage and re-gasification units (FSRUs) in 2015; plans for a third FSRU were canceled in 2016 because of higher anticipated domestic production. [6]. Much of the natural gas consumed in Egypt are used as fuels in electric power plants. The Egyptian government encourages households, businesses, and the industrial sector to consider natural gas as a substitute for petroleum products and coal. [7].

The Egyptian government has fasttracked the development of the Zohr and Atoll fields and the West Nile Delta (WND) project. These fields are expected to make substantial additions to the overall supply. Discovered in August 2015 and labeled as the largest offshore natural gas field in the Mediterranean, the Zohr gas field has an estimated reserve of $30(\mathrm{Tcf})(0.85(\mathrm{Tcm}))$ and is currently producing 2 (Bcf/d )$(0.0566(\mathrm{Bcm} / \mathrm{d}))$ [8]. Natural gas production at the Atoll field also began in February 2018 and is currently producing $0.35 \mathrm{Bcf} / \mathrm{d}$ $(0.01(\mathrm{Bcm} / \mathrm{d}))$ of natural gas and 10,000 barrels per day (b/d) of condensate. Production began seven months ahead of schedule and the field has an estimated 1.5 (Tcf) $(0.042(\mathrm{Tcm}))$ reserves of natural gas and 31 million barrels of condensates, with other areas still under evaluation. [9]. Developed as two separate projects to speed up development, the WND project started producing natural gas in March 2017 and is currently producing more than $0.7(\mathrm{Bcf} / \mathrm{d})$ $(0.02(\mathrm{Bcm} / \mathrm{d}))$ and $1,000 \mathrm{~b} / \mathrm{d}$ of condensate; the two projects are expected to be fully online in 2019 and to produce close to 1.5 $(\mathrm{Bcf} / \mathrm{d})(0.042(\mathrm{Tcm} / \mathrm{d}))$.

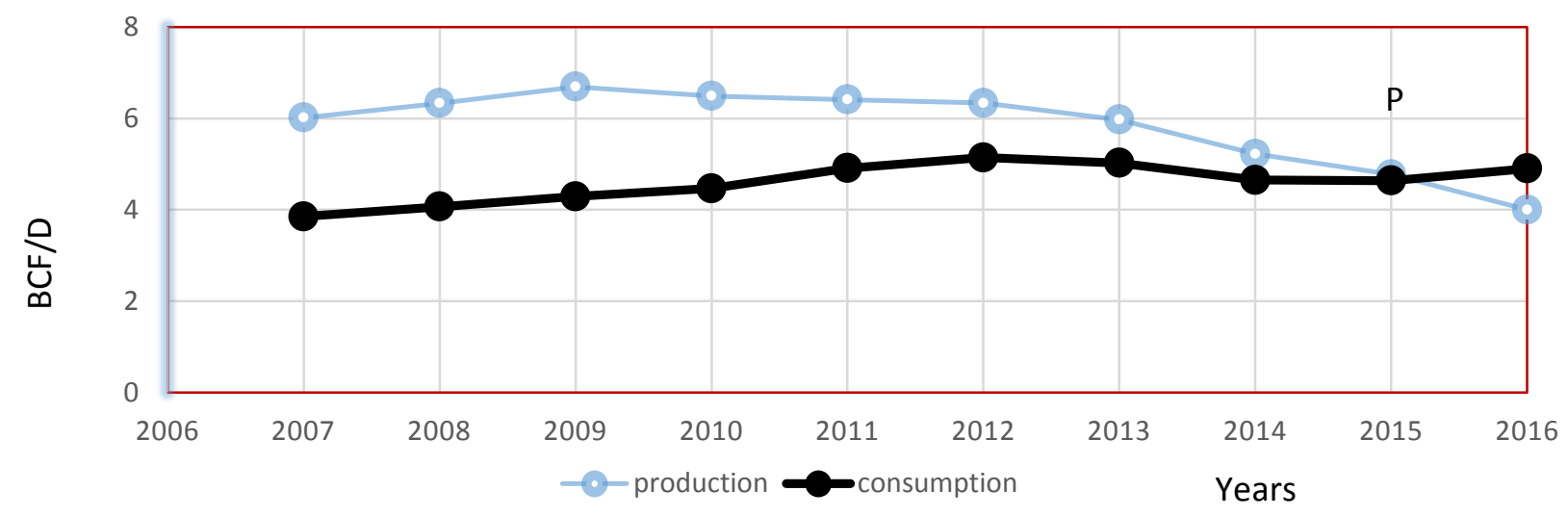

Fig. (1): production and consumption of NG in Egypt. 
From figure (1) it is clear that the period of exporting the Egyptian NG lies between 2007to 2014. The break point (P) between 2014 and 2015 shows the transport to importing the NG due to an increase in NG consumption.

\section{(B)International Natural Gas Productions:}

Final annual data are got from the U. S. Energy Information Administration's (EIA) and Natural Gas Annual (NGA). Some of the data for earlier months are estimated or computed. Preliminary yearly data are gathered from reports of the Interstate Oil Compact Commission and the U.S. Minerals Management Service. Volumetric data are converted, as necessary, to standard pressure base of 14.73 psia at $60^{\circ} \mathrm{Fahrenheit}$.

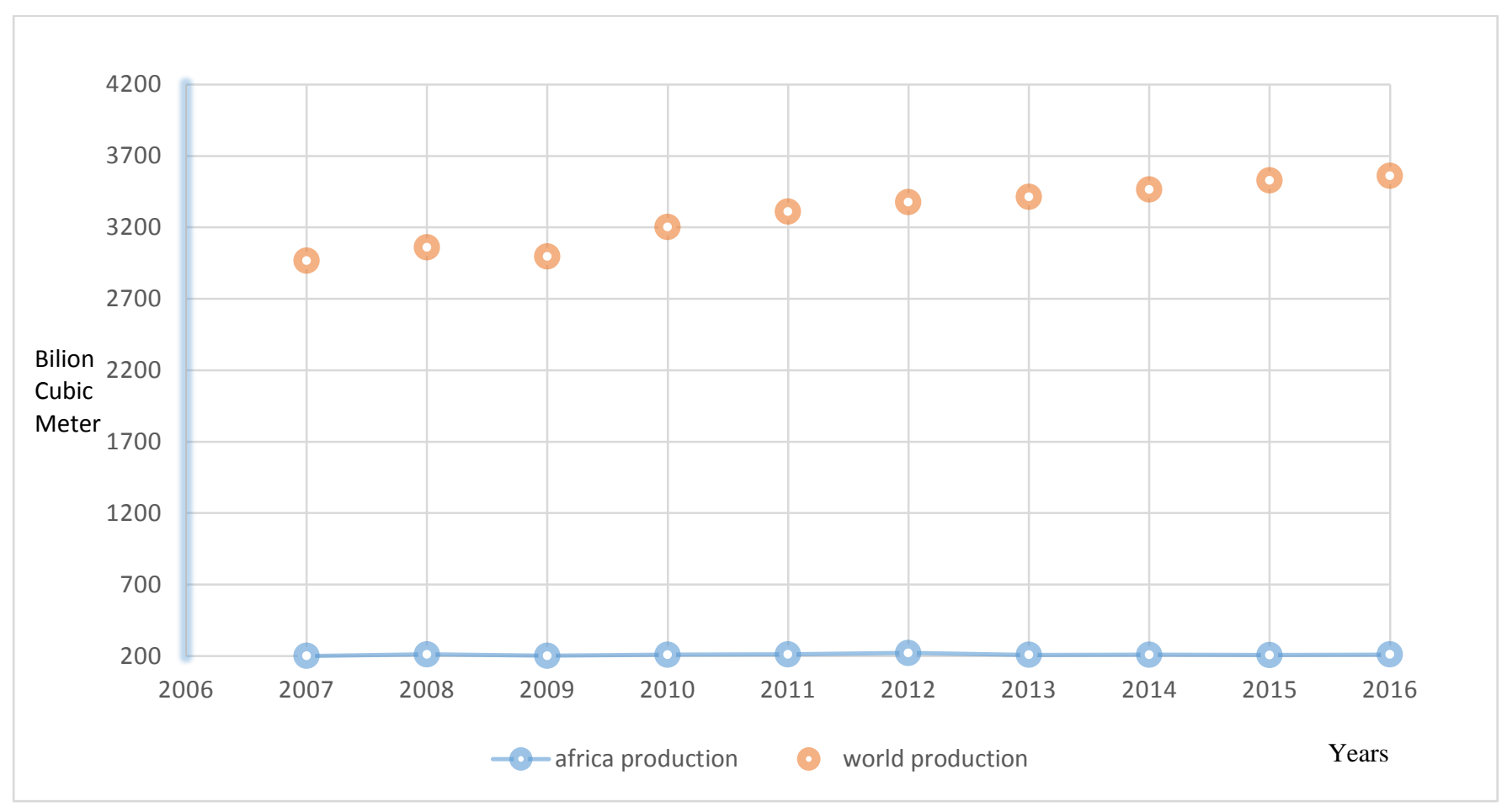

Fig. (2): Relative World and African Productions of NG.

Figure.(2), gives combarison between $\mathrm{N}$. G productions in Africa and overall productions in the world between the years 2007 and 2016, just for comparison. This may propose higher efforts to be done by the Africans and Arabs authorities for the near future.

\section{5- EXPECTED NG USES IN EGYPT:}

There are so many different applications for natural gas as a fuel; also it has many other applications. Commercially, in home, in industry, and even in the transportation sector.
While the uses described here are not exhaustive, they may help to show just how many things natural gas can do. Natural gas is used across all sectors, in varying amounts. The industrial sector accounts for the greatest proportion of using natural gas in Egypt. It - 112 - 
provides the base ingredients for such varied products as plastics, fertilizers, anti-freezes, and fabrics. Natural gas is the second most used energy source in industry, trailing only electricity. Lighting is one of the main uses of energy in the industrial sector. Industrial consumers reap great benefits from operating natural gas Combined Heat and Power (CHP) and Combined Cooling, Heat, and Power (CCHP) systems, similar to those used in commercial settings. For instance, natural gas can be used to generate the electricity needed in a particular industrial setting. The excess heat and steam produced from this process can be harnessed to fulfill other industrial applications, including space heating, water heating, and powering industrial boilers. Since industry is such a heavy user of energy, and particularly electricity, providing increased efficiency can save a great deal of money. The industrial sector is also subject to regulations regarding harmful emissions, and the burning attributes of natural gas help industry to reduce its emissions. Due to the new NG situation in Egypt, since the discovery of the Zohr, Attol, Noor and West Desert Fields, four petrochemical industries had been actually built in Egypt while some others are now in the contracting discussions. This petrochemical evolution had been thought - upon since the presence of the multi -discovered fields for natural gas reserves in Egypt.

\section{6-EGYPTIAN NG, HISTORY AND RESERVES:}

Dry natural gas exports, which began in 2003, have been rising rapidly, with the completion of the Arab Gas Pipeline (AGP) in 2004 and the startup of the first three LNG trains in 2005. However, after 2006 exports began to level off and in 2010, natural gas exports fell to $535(\mathrm{Bcf})(15(\mathrm{Bcm}))$, an almost $20 \%$ drop from the year before [10]. Egypt exports around $70 \%$ of total natural gas exports as $\mathrm{LNG}$, and the remaining $30 \%$ were exported via pipelines. THE ARAB Gas
Pipeline (AGP) originated in Egypt and provided gas to Jordan, Syria and Lebanon, with recent additions extending the pipeline to Turkey and European markets. Egypt has three LNG trains: C-gas LNG train 1 in Damietta and Egypt LNG trains 1 and 2 in Idku. The combined LNG export capacity is close to $600(\mathrm{Bcf} / \mathrm{y}),(17(\mathrm{Bcm} / \mathrm{y}))$ with plans to expand in the near future, pending export policy changes and legislation. In 2010, as domestic demand for natural gas increased, LNG exports fell to about $354 \mathrm{Bcf},(10(\mathrm{Bcm}))$ which was down by $30 \%$ from almost 500 (Bcf), (14(Bcm)) in 2009. In 2010, half of Egypt's LNG was shipped to Europe, which imported about $180(\mathrm{Bcf})(5(\mathrm{Bcm}))$, with over half of that destined for Spain 110 (Bcf) $(3(\mathrm{Bcm}))$. The US was the second largest recipient of Egyptian LNG in 2010, and imported just over 71 (Bcf), (2(Bcm)) [11]. In January 2012, Oil and Gas Journal (OGJ) estimated Egypt has proved gas reserves to reach 77 (Tcf) $(2.2(\mathrm{Tcm}))$, a significant increase compared to the 2010 estimates of 58.5 (Tcf) $(1.7(\mathrm{Tcm}))$. In terms of the natural gas reserves, Egypt ranks third in Africa, after Nigeria and Algeria. New discoveries offshore the Nile Delta and some finds in the Western Desert have led to the increase in proved reserves. Over $80 \%$ of Egypt's natural gas reserves and $70 \%$ of its production are located in the Mediterranean and the Nile Delta. Gas production is expected to continue to grow to satisfy rising domestic demand, export commitments through the Arab Gas Pipeline and LNG exports. Egypt is expected to continue to play an important role of a reliable natural gas supplier to Europe and the Mediterranean region, although exports are competing with rising domestic demand, particularly in the power generation sector. The share of natural gas consumed in the transportation sector has also been rising since the development and deployment of compressed natural gas (CNG) infrastructure and vehicles. According to the Ministry of Petroleum of Egypt, the number of natural gas 


\section{Vol. 39, No. 2. July 2020}

driven vehicles sold in Egypt between the fiscal years 2004/2005 and 2009/2010 has more than doubled. Major for- players involved in the development of Egypt gas sector include Eni, Britch Gas (BG) Group, Britch Petroleum(BP) \& Apache and Gasco.

\section{7- FUTURE PROSPECTS FOR EGYPTIAN EVALUATION}

After more than a decade of a roller coaster ride of Egypt's gas sector, leading even to importing LNG for years, Egypt seems now to be heading to a brighter future. The extreme success stories offshore Mediterranean, as represented by Italian oil major ENI's production on the Zohr gas field and possible Noor reserves, only show that Egypt is fully able to rejoin the gas export market again in full very soon. The Egypt/Cyprus/Greece deep-water gas pipeline project is another additional success. Some clarification is still needed here, while commercial risks already show that a more rational pure LNG export strategy is needed some days ago, Egypt's Minister of Petroleum has stated that the ENI's huge Zohr gas field offshore Egypt has increased its production six-folds since it started production in January 2018. Total production at present is said to be around 2 (Bcf/d) $(0.0566(\mathrm{Bcm} / \mathrm{d})), \quad$ a staggering increase from the $350 \mathrm{mcf}$ per day in January. For 2019, a production platform targeted by ENI of around 2.7 Bcf per day. [12]. The production increase during 2018 has already resulted in a situation that no more LNG imports are needed at present. Egypt has already anticipated these developments, as it stated in June 2018 that no newer LNG import tenders would be published. Egypt has been able to set up a strategy in which it could become a major energy-trading hub in the region. Gas production in Egypt in the coming years is expected to increase substantially, not only by already anticipated volumes offshore Mediterranean but also due to production increases or those new discoveries in the Western Desert.
The Arab Gas Pipeline (AGP). Is away by which Egypt began exporting natural gas and which has been originated in Egypt and connects to Jordan, Syria, and Lebanon. Egypt halted natural gas exports to it by canceling its long-term supply contract to Israel because of a payment dispute. [13]. AGP pipeline exports, which peaked at 0.5 Bcf/d in 2009, stopped after 2014 [14]

Liquefied Natural Gas (LNG) is another way for exporting NG the Suez Canal transit route also has having flow in both directions and accounting for a substantial amount of global LNG trade. Southbound LNG transit primarily originated in Nigeria, France (as reexports), also Trinidad and Tobago, and most LNG is exported to Egypt, Jordan and Japan. Nearly all-northbound transit originates from Qatar and is exported to European markets. Egypt has two LNG export facilities with a combined capacity of 586 Bcf per year. [15]

\section{8 -CONCLUSION:}

In the year2016 Egypt produced approximately $4.0(\mathrm{Bcf} / \mathrm{d})(0.1132(\mathrm{Bcm} / \mathrm{d}))$ of dry natural gas and imported $(1.0 \mathrm{Bcf} / \mathrm{d})$ $(0.028(\mathrm{Bcm} / \mathrm{d}))$. Zohr field was discovered in August 2015 and labeled as the largest off shore natural gas field in the Mediterranean region. By the end of 2019 Natural gas will have a multitude of industrial uses, including providing the base ingredients for such varied products as plastics, fertilizers, anti-freezes, and fabrics. It is the second most used energy source in industry, trailing only electricity. Until now (May2019), Egypt is still in discussion with Greece, Cyprus and others, on a possible offshore deep-water gas pipeline project, which would connect the offshore finds of all parts to the European market. Moreover, Egypt has many of facelifts to export natural gas to the world such as (AGP), and also as LNG. 


\section{Vol. 39, No. 2. July 2020}

\section{9 -RECOMMENDATIONS}

One of the world's most prolific gas regions, the Middle East, is currently witnessing extremely high activity. In addition to Egypt's success with the giant offshore Zohr gas field and ongoing projects in Cyprus and Lebanon, the region is shaping up to become an important LNG exporter. Within the last few years, recommendations are mainly, all or some of the following:

- focusing on the need for a gas export strategy, involving Cyprus, the gas producer Egypt. and others, to supply international LNG markets.

- Discussions on offshore deep-water gaspipelines from Cyprus, and an onshore additional gas pipeline from elsewhere from Israel, with the LNG production and export in Egypt to bring enough gas volume to a central point to make the production and export of LNG economically feasible.

- Developing the offshore Noor gas field, which is slated for holding possible reserves of around 90Tcf, which is expected to be triple the size of the Zohr field.

- Optimal utilization of gas and petroleum in the Petrochemicals industry in chemical engineering objectives other than using as fuel.

-The safe of using new and renewable energies and peaceful nuclear energy and coal, to generate electricity- saving the greatest amount of oil and gas for Petrochemicals industry, taking all environmental precautions

- The need to provide Petrochemicals industry with the sufficient governmental support; regarding funding, land allocation, technical support and provision of some facilities.
- Encouraging the participation of the Egyptian private sector to engage in Petrochemicals industry directed from the local market to the African and Arab markets, transforming Egypt into a global center for the trading and storage of Petrochemicals products, as it is actually going on for the expected Egyptian strategy.

\section{0- REFERENCES}

1: Ministry Hierarchy," Arab Republic of Egypt, Ministry of Petroleum, http://www.petroleum.gov.eg/en/AboutMinistry/P ages/Heirarchy.aspx. Accessed 3/5/2018,

2: GUPCO inlet gas, sales gas and other companies red sea, EGYPT 2019.

3: "Zohr Gas Field," www.offshoretechnology.com, accessed https://www.offshoretechnology.com/projects/zohr-gas-field/. "Egyptian gas sector poised for growth,"

www.newsbase.com, Afroil Issue 721, Week 1, January 9, 2018, pg. 6. "Zohr: from promise to reality," www.eni.com,

Accessed 3/30/2018,

4: Worldwide look at reserves and production, Oil and Gas Journal, January 1, 2018; January 1, 2010 .

5: "BP announces start of production from West Nile Delta development achieving first gas eight months ahead

of schedule and production 20 percent above plan," BP company press release, May 10, 2017, accessed 3/30/2018,

6: "Ministry Hierarchy," Arab Republic of Egypt, Ministry of Petroleum, accessed 3/5/2018,

http://www.petroleum.gov.eg/en/AboutMinistry/P ages/Heirarchy.aspx. "Egypt Oil and Gas Report Q4 2017,"

BMI Research, p. 65August 2017,

7: Egypt LNG Market Report," IHS Market, November 7, 2017 


\section{Vol. 39, No. 2. July 2020}

8: "Eni strikes Zohr sale deal," www.newsbase.com, Afroil Issue 730, Week 10, p. 7. March 13, 2018,

9: BP begins production from Egypt's Atoll gas field seven months ahead of schedule," BP Company Press

Release, February 12, 2018, accessed 3/30/2018,

https://www.bp.com/en/global/corporate/media/pr ess-releases/bp-

Begins-production-from-egypts-atoll-gasfield-seven-months-ahead-of-schedule.html. 10: BP 2017 Statistical Review of World Energy, historical database, accessed 3/27/2018,

https://www.bp.com/en/global/corporate/energyeconomics/statistical-review-of-worldenergy.html. IHS Markit, Egypt

LNG Market Report, Data Sheet, March 23, 2018.

11: Egypt: SEGAS LNG," IHS Market, Liquefaction Project Profile, December 1, 2017. Paul Day and Oleg Kuzmanovic.

"Update 1 - Damietta LNG Plant Idled as Egypt Keeps its Gas at Home," Reuters, February 7, 2013, accessed

$3 / 28 / 2018$

https://www.reuters.com/article/gas-naturalegypt/update-1-damietta-lng-plant-idled-as-egyptkeeps-its-gas-

At-home-idUSL5N0B7HKW20130207.

12: BP 2017 Statistical Review of World Energy, historical database, accessed 3/27/2018,

https://www.bp.com/en/global/corporate/energyeconomics/statistical-review-of-worldenergy.html. IHS Market, Egypt

LNG Market Report, Data Sheet, March 23, 2018.

13: The Guardian magazine, "Egypt Cancels Israel Gas Contracts," London (April 23, 2012).

14: BP 2017 Statistical Review of World Energy, historical database, accessed 2/26/2018, 


\section{حول الغاز الطبيعي المصري: الواقع والتاريخ والتوقعات}

نظرا لما يشكله الغاز الطبيعي المصري كمصدر هام للطاقة يستخدم في كثير من الصناعات منل صناعات البتروكيماويات والاسمدة واستخدامه كمصدر للطاقة وأيضا استخدامه كوقود للمنازل والصناعات المختلفة منل الحديد والصلب والأسمدة والاسمنت مما جعل جميع دول العالم تهتم بصناعة الغاز وتتمية الحقول وتسهيل عمليات الإنتاج.

كانت مصر في عام 2013 تتتج حوالي اربعة بلايين قدم مكعب من الغاز يوميا وتستورد حوالي بليون قدم مكعب منة يوميا وبالتالي كانت زيادة استهلاك الغاز الطبيعي تشكل ضغط علي الحكومة المصرية من خلال توفير النقد الأجنبي للاستيراد و لذلك كان لابد من إيجاد حلول وبدائل اخري من خلال اكتشاف ابار انتاج جديدة وتتمية الابار المستخدمة في الوقت الحالي ووضع كثير من الابار والحقول علي خط الإنتاج لتلبية الطلب المتزايد علي الغاز الطبيعي وفي شهر أغطس عام 2015 تم اكتثاف حقل غاز ظهر في البحر المتوسط من خلال شركة ايني الإيطالية وهو اكبر حقل غاز في مصر ومنطقة شرق المتوسط باحتياطي يقدر بحوالي ثلاثثن نريليون قدم مكعب غاز وسوف ينتج بليوني قدم مكعب من الغاز الطبيعي مع نهاية عام 2019. وبوضع هذا الحقل على خريطة الإنتاج فقد ساعد ذلك الحكومة المصرية على توفير العملة الصعبة من خلال عدم استيراد الغاز الطبيعي مع نهاية عام 2018 وبالتالي تتمية خزانة الدولة بمبلغ يصل الي 2.7 مليار جنية سنويا وتوجيه تكلفة الاستيراد الي الرعاية الصحية والخدمات المختلفة للمواطنين. وفي نهاية عام2 2018 أصبحت الحكومة المصرية قادرة على حلى تصدير الغاز الطبيعي مرة اخري بعد ان توقفت عمليات التصدير التي كانت تتم في الماضي حتى عهد قريب للحصول على العملة الصعبة. و الدولة المصرية تملك الان مقومات وبنية تحنية عالية في مجال تسييل الغاز الطبيعي وإعادة تصديره وذلك لما تشكله مكانة مصر الجغرافية من أهمية عالية ولوجودها في قلب منطقة الثرق الأوسط ووجود قناة السويس التي أصبحت قناتين لزيادة ربط البحر الأبيض المتوسط بالبحر الاحمر من خلال مرور سفن تسييل الغاز الطبيعي من افريقيا الي منطقة أوروبا وأيضا لوجود مصنعين لنسييل الغاز الطبيعي.( مصنع بالإسكندرية بمنطقة ادكو والأخر بمنطقة دمياط) وأيضا لوجود خط الغاز العربي الذي يربط بين مصر والأردن وسوريا ولبنان ،كل هذه التسهيلات جعلت من مصر مركزا إقليميا للطاقة و تسعي مصر الان الي تشينه في صورة استراتيجية، ليصبح مستقبل الغاز في مصر مبشرا بطفرات في الإنتاج تؤدي بعون اللة تعالي الي زيادة نصيب الفرد السنوي من دخل الدولة. 